\title{
Marcas do encontro de um corpo lusófono e de um corpo indo-ariano na
} Índia Portuguesa

\section{Resumo}

Valéria Noronha Vaccarelli (IC)

O objetivo principal foi desenvolver uma pesquisa a partir de fontes bibliográficas, imagens, textos, cartas, sobre o que consideramos uma diáspora da cultura lusófona no oriente, precisamente na Índia Portuguesa, na Costa do Malabar e no atual Estado de Goa na República da Índia. Considerando este padre, soldado e mercador, figuras que se misturam muitas vezes em um só homem, busquei destacar quais as contribuições e influências que marcaram a construção do conhecimento, ciências, arte, com foco em um corpo marcado pelo encontro destas culturas.

$$
\text { Corpo - Lusofonia - Índia }
$$

\section{Introdução}

Consideramos que a combinação entre as missões jesuíticas, as grandes navegações, mas, sobretudo o encontro do homem português, espécie de mistura entre o soldado, padre e mercador, como o homem indo-ariano e as outras culturas já instauradas na costa do Malabar deixou marcas e referências que contribuem para pensar este encontro oriente/ocidente e a consequente construção do conhecimento nas artes, na ciência e na estética contemporânea.

$E$, neste encontro, em que o europeu invade e ocidentaliza 0 oriente e é também indianizado e orientalizado.

Os europeus iniciam um contato com uma sociedade totalmente distinta da sua, e quanto mais profundo o contato, maior será a discrepância.

Destacam-se as dificuldades encontradas pelas frotas portuguesas, que foram instituindo feitorias e abarcando territórios e a efetiva conquista com a chegada do governador Afonso de Albuquerque que dominou Goa, Malaca e Ormuz.

Note-se também a destruição dos templos indianos, a construção de grandes monumentos cristãos em oposição à grandeza dos templos hindus, a tentativa de imposição da onipresença cristã.

Esta "invasão" deixa muitas marcas arquitetônicas que se misturam com as deixadas em todos os lugares por onde a dominação portuguesa passou.

\section{Resultados e Discussão}

Como principal resultado da pesquisa apontamos a sistematização de dados e conhecimentos sobre a colonização portuguesa de Goa. Também é necessário ressaltar o aumento do estoque de conhecimento no âmbito das teorias do corpo, o que aumenta a possibilidade de projetos, pesquisas comuns e intercâmbios científicos e artísticos entre Brasil e a República da Índia.

\section{Conclusões}

Ressalta-se que as marcas deixadas em todos os envolvidos, seja no oriente pela presença física que resistem ainda hoje, seja no ocidente com as influências que transparecem na mudança da disciplina do corpo com os preceitos do yoga e da não violência, na filosofia oriental que encabeça a construção de novos paradigmas científicos, nas artes, e na construção da modernidade.

\section{Agradecimentos}

\section{BIBLIOGRAFIA}

AGUALUSA, José Eduardo. Um estranho em Goa, Ed. Gryphus, Rio de Janeiro, 2001.

BIANCHINI, Flávia. A origem da civilização indiana no vale do Indo-Sarasvati: teorias sobre a invasão ariana e suas críticas recentes. Pp. 57-108, in: GNERRE, Maria Lúcia Abaurre; POSSEBON, Fabrício (orgs). Cultura oriental: língua, filosofia e crença. Vol. 1, João Pessoa: Editora da UFPB, 2012.

BRAUDEL, Fernand. Gramática das civilizações. Trad. Antônio de Pádua Danese, São Paulo: Martins fontes, 1989. CAMÔES, Luís. Os Lusíadas, Edição escolar comentada pelo Prof. Otoniel Mota, Ed. Melhoramentos, 11aㅡ Ed., São PauloSP, 1957.

DELLON, Charles. Narração da Inquisição em Goa.Tradução Miguel Vicente de Abreu, Edições Antigonas, 2a edição, Libsoa, 1996.

GREINER, Christine. O Corpo: Pistas para estudos indisciplinares, Ed. Annablume, $2^{\mathrm{a}}$ edição, 2206.

MORAIS, Carlos Alexandre. Cronologia Geral da ÍndiaPortuguesa - 1498-1962, referência editorial estampa, $2^{\mathrm{a}}$ edição revisada e aumentada, Lisboa, 1996.

PEREIRA, Antônio Nunes. A Arquitectura Religiosa cristã da Velha Goa: Segunda metade do sec.XVI - primeiras XVII, Fundação Oriente, Lisboa, 2005.

REGO, Antonio da Silva. Estudos de História Luso-Africana e oriental, séculos XVI-XIX, Academia Portuguesa da Histórica, Lisboa, 1950.

TAVARES,Célia Cristina da Silva. Jesuítas e Inquisidores em Goa: a cristandade insular (1540-1682), Roma editora, Lisboa, 2004. 